\title{
SECREÇÃO DE INSULINA: ENVOLVIMENTO E IMPORTÁNCIA DO CÁLCIO
}

\author{
EDSON DELATTRE*
}

\section{RESUMO}

Revisão bibliográfica abordando aspectos da participaçāo e importância do cálcio na secreção de insulina, tratando inicialmente da necessidade desse ion para a açäo insulinotrópica de inumeros secretagogos. Essa necessidade tem sido demonstrada em variadas condiçoes experimentais, in vitro $e$ in vivo, através de diferentes abordagens metodológicas. Consideram-se ainda, aspectos da compartimentalização do cálcio nas células beta, ressaltando a participação do estado glicêmico do organismo em determinar rearranjos na sua distribuição entre os compartimentos. Finalmente, com base na idéia de que o evento primário que conduz à secreção de insulina è o aumento do cálcio ionizado da célula beta, enfoca a função citofisiológica especifica desse cátion, como ativador do processo contrátil dos microtúbulos e lou como deletor de cargas elétricas na célula beta.

\section{1 - INTRODUÇÃO}

A participação de íons $\mathrm{Ca}^{2+}$ em processos de acoplamento estímulosecreção tem sido constatada em diferentes estruturas nervosas e endócrinas (BIRMINGHAM, ELLIOTT \& VALĖRE(5); HUTTER \& KOSTIAL(36); DOUGLAS (16); WILLIAMS(64); LUNDQUIST, FANSKA \& GRODSKY(42); IVERSEN \& HERMANSEN(37), Para revisão, vide RUBIN(61), RUBIN (62) e HALES et alii(23)).

À semelhança do acoplamento excitação-contração em células musculares, acredita-se que um aumento na concentração do cálcio ionizado em um compartimento crítico do citosol da célula beta conduza à exocitose dos grânulos de insulina. Outrossim, sabe-se que inúmeros agentes que estimulam ou inibem a secreção de insulina, o fazem através de uma interferência com os fluxos transmembranares de íons, dentre eles o cálcio.

Revisões que tratam do papel do $\mathrm{Ca}^{2+}$ na secreção de insulina foram feitas por MALAISSE(43), MALAISSE \& PIPELEERS(47) MALAISSE(45), MALAISSE et alii( 58 ) e WOLLHEIM \& $\operatorname{SHARP}(66)$.

O objetivo primordial desta revisão é evidenciar experimental e clinicamente o papel do cálcio no processo de secreção de insulina.

\section{2 - EVIDENCIAS DO PAPEL DO CÁLCIO}

A importância transcendental do $\mathrm{Ca}^{2+}$ citosólico, no processo de secreção de insulina, tem dirigido a atenção de inúmeros pesquisadores para esse campo de estudos (MALAISSE(43), BRISSON MALAISSE-LAGAE \& MALAIS$\mathrm{SE}^{(8)}$; MALAISSE(44). MALAISSE \& PIPELEERS(47); ATWATER \& BEIGELMAN( $(2)$; SOMERS et alii(63); MALAISSE et alii $(57,58)$, dentre outros. E amplamente aceito que o evento primário que conduz à secreção de insulina ê o aumento do cálcio ionizado do citosol da célula beta (MALAISSE $^{(43)}$; ATWATER \& BEIGELMAN $(2)$ ). Ainda segundo esses autores, o conceito de que a acumulação de $\mathrm{Ca}^{2+}$, em um "sítio crítico" da célula beta, provoca a secreção, tem duas grandes implicações. 10.) Agentes que estimulam ou inibem a secreção de insulina o fariam alterando o manuseio de $\mathrm{Ca}^{2+}$ pela célula beta; 20 .) $\circ \overline{\mathrm{Ca}}^{2+}$ poderia desencadear a secreção de insulina através de uma modalidade simples e invariável. $\mathrm{O} \mathrm{Ca}^{2+}$ excerceria um controle múltiplo sobre a função da célula beta. em que um suprimento suficiente-de $\mathrm{Ca}^{2+}$ seria requerido para (a) manter o reservatório celular de $\mathrm{Ca}^{2+}$ que medeia a secreção de insulina e (b) regular os processos consumidores de energia, possivelmente locali- zados na membrana celular (MALAIS$\mathrm{SE}$ et alii( $\left.{ }^{(57)}\right)$. De acordo com MALAISSE et aliii (52), a estimulação da secreção de insulina, provocada por certos açúcares, aminoácidos, potássio, AMPc ou sulfoniluréias, e a inibiç̃̃o da secrecão, causada por $\mathrm{Mg}^{2+}$, adrenalina, diazóxido, anestésicos locais e inibidores metabólicos, sempre resultam de alterações no transporte ou na distribuição de $\mathrm{Ca}^{2+}$ na célula beta. Perfundindo pâncreas isolado de rato, GRODSKY \& BENNETT(22) foram os primeiros a constatar a necessidade de íons $\mathrm{Ca}^{2+}$ no meio extracelular, para a ocorrência de secreção de insulina. Essa verificação foi confirmada, em idêntica preparação, por CURRY, BENNETT \& GRODSKY (10); em fragmentos de pâncreas de coelho, por MILNER \& HALES(59); em fragmentos de pâncreas de rato, por MALAISSE. BRISSON \& MALAISSE-LAGAE(49); em pâncreas de rato, mantido em cultura, por LAMBERT et alii(40); em ilhotas isoladas de rato, por MALAISSE, BRISSON \& BAIRD $^{(50)}$ e HELLMAN $(26)$ e em preparações de membranas e grânulos de secreção isolados, por DAVIS \& LAZARUS(11)

A importância do $\mathrm{Ca}^{2+}$ para a secreção de insulina tem sido demonstrada, também, através do emprego de substâncias que promovem a sua captação através das membranas (ionó-

\footnotetext{
* Professar Assistente de Fisiologia da Universidade Estadual de Londrina.
} 
foros) (FUJIMOTO \& ENSINCK(17)) ou inibem essa captação (antagonistas) (DEVIS et alii(15); MALAISSE et alii $(53,54,56)$; SOMMERS et alii( 63 ) MALAISSE(46); MALAISSE \& BOSCHERO (48). Assim, ASHBY \& SPEAKE; CONAWAY et alii e WOLLHEIM, BLONDEL \& SHARP, apud SEDDESKOV(25), verificaram que o ionóforo lipossolúvel A23187, que liga cátions divalentes e intensifica a entrada de cálcio nas células, estimulou significativamente a secreção de insulina em diversas preparações in vitro. Outrossim, BENNETT, CURRY \& GRODSKY $(4)$, empregando $\mathrm{Mg}^{2+}$, HENQUIN \& ' LAMBERT (30) utili' zando $\mathrm{Co}^{2+}$, MALAISSE et alii(55) com o verapamil, BOSCHERO, DELATTRE \& SANTOS(7) e DELATTRE, SANTOS \& BOSCHERO (12) com antibióticos aminoglicosídicos (dentre diversos outros pesquisadores que usaram vários inibidores), constataram redução da secreção de insulina in vitro, em meio normocalcêmico.

O $\mathrm{Ca}^{2+}$ é necessário, não somente para a ação estimulatória da glicose sobre a secreção de insulina mas, também, para a ação de outros agentes, como sulfoniluréias (CURRY, BENNETT \& GRODSKY(10); MALAISSE et alii $(52)$, aminoácidos, potássio, AMPc e carboidratos insulinotrópicos (MALAISSE et alii( 52$)$ ).

$\operatorname{HELLMAN}(26,28)$ considera importante, para a secreção de insulina, um nível ótimo de $\mathrm{Ca}^{2+}$ nos reservatórios funcionais deste cátion na célula beta. Em concordância com esta idéia, temse observado que, dentro de um certo intervalo, a secreção de insulina guarda relação direta com o nível de $\mathrm{Ca}^{2+}$ do meio extracelular (CURRY, BENNETT \& GRODSKY $(10)$; FUJIMOTO \& ENSINCK(17). Uma elevação da concetração extracelular de $\mathrm{Ca}^{2+}$ provocaria um aumento na entrada de $\mathrm{Ca}^{2+}$ e/ou inibição do seu efluxo, gerando um suficiente acúmulo desse ion na célula beta, estimulando, assim, a secreção (DEVIS, SOMERS \& MALAISSE( $\left.{ }^{14}\right)$.

MALAISSE \& PIPELEERS (47) e PIPELEERS, MARICHAL \& MALAI$\operatorname{SSE}(60)$ sugerem que a participação de cátions divalentes, especialmente o $\mathrm{Ca}^{2+}$, no acoplamento estímulo-secreção, ocorre em uma etapa final e essencial da sequêencia secretória de insulina. Por sua vez, HENQUIN (29) conclui que a mera presença de $\mathrm{Ca}^{2+}$ extracelular não é suficiente para a estimulação, pela glicose, da secreção de insulina, mas que deve ocorrer um influxo 340 desse íon na célula beta. Esse mesmo autor considera que a necessidade de $\mathrm{Ca}^{2+}$ extracelular parece ser absoluta para a fase inicial, e menos completa para a segunda fase da secreção. Uma verificação conflitante com essa ê, no entanto, relatada por WOLLHEIM et alii(67)' e KIKUCHI et alii(38). Esses concluem que a primeira fase de resposta à glicose é gerada pela utilização do $\mathrm{Ca}^{2+}$ intracelular, enquanto a segunda fase requer, para seu pleno desenvolvimento, tanto $\mathrm{o} \mathrm{Ca}^{2+}$ intracelular, quanto a elevada captação do $\mathrm{Ca}^{2+}$ extracelular. Já GRODSKY et alii, apud HEDESKOV(25), verificaram que ambas as fases da secreção de insulina estavam diminuídas na ausência de cálcio extracelular.

Ao contrário do que se tem constatado em relação à secreção, a síntese de insulina parece prescindir do $\mathrm{Ca}^{2+}$ extracelular (CURRY, BENNETT \& GRODSKY (9); PIPELEERS, MARICHAL \& MALAISSE(60).

Por outro lado, alguns estudos têm mostrado que o $\mathrm{Ca}^{2+}$, por si só, pode provocar secreção de insulina na ausência de glicose (DEVIS, SOMERS \& MALAISSE (13); WOLLHEIM et alii(68); HELLMAN(27); DEVIS, SOMERS \& MALAISSE( 14 )

\section{1 - Constatações Clínicas}

Clinicamente, também se tem verificado a importância do $\mathrm{Ca}^{2+}$ para a secreção de insulina. Assim, AMEND Jr. et alii( $(1)$, BANSAL et alii( (3), YASUDA et alji (69) e GEDIK \& ZILELI(19) detectaram resposta insulínica reduzida em pacientes hipocalcềmicos submetidos a sobrecarga de glicose. O mesmo se constatou em mamíferos não-primatas (LITTLEDIKE, WITZEL \& WHIPP(4i); WITZEL \& LITTLE$\operatorname{DIKE}(65)$. Outrossim, nas hipercalcemias, um aumento da secreção de insulina, desencadeada por vários agentes, tem sido constatado (a) em humanos submetidos a sobrecarga de glicose (YASUDA et alii(69); FUJITA et alii(18); GEDIK, AKALIN \& KORAY $(20)$ ou tratados com a sulfoniluréia glibenclarnida (GERÓ et alii(21) e (b) em cães infundidos com glicose (KUZUYA. KAJINUMA \& IDE(39) ou tolbutamida (HARTER et alii( $(24)$ ).

\section{3 - RESERVATÓRIOS DE CÁLCIO}

A localizaçã de reservatórios intracelulares de $\mathrm{Ca}^{2+}$ e sua participação no mecanismo de secreção de insulina têm sido objeto de estudos de alguns pesquisadores. HERMAN, SATO \& HALES(31), empregando a técnica do piroantimoniato, seguida de microscopia eletrônica, verificaram que os maiores depósitos situam-se nas vesículas secretórias, nas mitocôndrias e na membrana celular. Observaram, também, que a incubação das ilhotas, em meio com $16,7 \mathrm{mM}$ de glicose, aumenta a deposição de precipitados de piroantimoniato nas vesículas secretórias e na membrana celular. Em harmonia com esses resultados, SCHÃFER \& KLÖPPEL, apud HEDESKOV(25); verificaram que, em camundongos normoglicêmicos, precipitados eletroopacos de piroantimoniato contendo $\mathrm{Ca}^{2+}$ estavam associados com membranas granulares, membranas plasmáticas e matriz citoplasmática, enquanto durante hipoglicemia os precipitados deslocaram-se para o retículo endoplasmático e mitocôndrias. Em camundongos hiperglicêmicos, intensificaram-se os depositos na superfície interna da membrana plasmática e nos envelopes dos grânulos de secreção. HEDESKOV(25) considera esses resultados como indicadores de que o metabolismo normal da glicose nas ilhotas previne a captação (pelas mitocôndrias e retículo endoplasmático) do cálcio citosólico livre.

BLOOM et alii( 6 ) sustentam que os grânulos secretórios constituem uma parte considerável do estoque de $\mathrm{Ca}^{2+}$ glicose-sensivel da célula beta. A importância das mitocôndrias na regulação da concentração de $\mathrm{Ca}^{2+}$ citosólico nas células beta foi confirmada por HOWELL \& TYHURST(34), empregando $\mathrm{Ba}^{2+}$ como traçador daquele cátion; por HOWELL \& TY. HURST(33), através da auto-radiografia e por HOWELL(32), com o uso de microanálise de raio $X$. Apesar de controvérsias quanto ao papel específico de cada reservatório, parece que o $\mathrm{Ca}^{2+}$ está distribuído entre, no mínimo, dois reservatórios. Um, representado pelo $\mathrm{Ca}^{2+}$ citosólico, e outro, heterogêneo, que corresponde ao $\mathrm{Ca}^{2+}$ captado por, ou ligado a, várias organelas (MALAISSE \& PIPELEERS(47)). HOWELL. MONTAGUE \& TYHURST(35) sugerem que os reservatórios lábeis de $\mathrm{Ca}^{2+}$, a nível de mitocôndrias e retículo endoplasmático, desempenham um papel predominante na regulação da concentração do cálcio citoplasmático livre. 
4 - FUNÇÃO DO CÁLCIO

Ainda se desconhece a função precisa do $\mathrm{Ca}^{2+}$ no processo de secreção de insulina. Segundo a hipótese do movimento granular dirigido por microtúbulos, $\mathrm{O} \mathrm{Ca}^{2+}$ poderia estar envolvido na estimulação de proteínas contráteis nesses microtúbulos (MALAISSE et alii(51). DEAN, apud HEDES$\operatorname{KOV}(25)$, conjectura sobre o fato de que, uma vez o grânulo secretório tenha sido transportado para uma posição adjacente à membrana plasmática, ele assim seria mantido pelo equilíbrio entre forças de van der Waals, de atração e repulsão eletrostáticas. Um aumento na concentração citosólica de $\mathrm{Ca}^{2+}$, na região subjacente à membrana plasmática, reduziria a carga elétrica $\mathrm{e}$ a repulsão eletrostática e poderia, então, ocorrer a fusão das vesículas com a membrana. Nesse sentido, DAHL \& GRÄTZL, apud HEDESKOV('25), observaram a ocorrência de fusão intervesicular in vitro, quando se adicionou $\mathrm{Ca}^{2+}$ em quantidade adequada ao meio de incubação.

5 - CONCLUSÃO

A presença de cálcio é essencial para a secreção de insulina estimulada por diferentes secretagogos. A secreção depende de um aumento na concentração de $\mathrm{Ca}^{2+}$ em um sítio crítico da célula beta. Esse cátion participaria de uma etapa final e essencial da sequiência secretória, embora sua exata função, a nível molecular, não esteja ainda esclarecida. Na célula beta, encontra-se distribuído entre, no mí. nimo, dois compartimentos: o citosólico e o particulado. Sua distribuição, entretanto, sofre rearranjos, que são determinados pelo estado glicêmico do organismo.

\section{ABSTRACT}

This review of literature focuses on aspects of the involvement and importance of calcium in insulin release, dealing initially with the need of this ion for the insulinotropic action of inumerable secretagogues. This need has been shown under various experimental conditions, in vitro ana in vivo, by several methodological approaches. It also treats aspects of calcium compartmentalization in - beta cells, pointing out the involvement of a glycemic state in the organism in determining rearrangement in its distribution among the compartments. Finally, based on the notion that primary event which directs insulin release is the increase of the ionized calcium level in the beta cell cytosol, it focuses on the specific cytophysiological function of this cation as the trigger of the microtubular contractile process and/or as the deleter of electrical charges in the beta cell.

\section{REFERENCIAS BIBLIOGRÁFICAS}

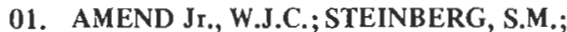
LOWRIE, E.G.; LAZARUS, J.M.; SOELDNER. J.S.: HAMPERS. C.L.; MERRIL, J.P. The influence of serum calcium and parathyroid hormone upon glucose metabolism in uremia. J. Lab. clin. Med., 86: $435-44,1975$.

02. ATWATER, I. \& BEIGELMAN, P.M. Dy namic characteristics of electrical activity in pancreatic B-cells $I$. Effects of calcium and magnesium removal. J. Physiol., Paris, 72: $769-86,1976$

03. BANSAL, S.; RIZVI, S.N.A.; RAO, M.B.; VAISHNAVA, H. Effect of hypocalcaemia on glucose tolerance, insulin release and free fatty acid levels in human subjects. Post, Grad. med. J, 51:471-5, 1975.

04. BENNETT, L.L.; CURRY, D.L.; GRODSKY, G.M.

Calcium-magnesium antagonism in insulin secretion by the perfused rat pancreas. Endocrinology, 85: 594-6, 1969.

05. . BIRMINGHAM, M.K.; ELLIOTT, F.H.; VALERE, P.H. - L. The need for the presence of calcium for the stimulation in vitro of rat adrenal glands by adrenocorticotrophic hormone. Endocrinology, 53: $687-9,1953$.

06. BLOOM, G.D.; HELLMAN, B.; SEHLIN,
J.; TALJEDAL, I. - B. Glucose- . stimulated and $\mathrm{La}^{3+}$ nondisplaceable $\mathrm{Ca}^{++}$pool in pancreatic islets. Amer. J. Physiol., 232: E114-E118, 1977.

07. BOSCHERO, A.C.; DELATTRE, E.; insulin release by the aminoglycoside antibiotic sisomycin. Horm. metabol. Res., 13:531-2, 1981.

08. BRISSON, G.R.; MALAISSE-LAGAE, F.; MALAISSE, W.J. The stimulus-secretion coupling of glucose-induced insulin release VII. A proposed site of action for adenosine-3', 5'-cyclic monophosphate. J. clin. Invest., 51:232-41, 1972.

09. CURRY, D.L.; BENNETT, L.L.; GRODSKY, G.M. Dy namics of insulin secretion by the perfused rat pancreas. Endocrinology, 83 . $572-84,1968$.

10. _- _. ; _ . ; - - Requirement for calcium ion in insulin secretion by the perfused rat pancreas. Amer. J. Physiol., 214: 174-8, 1968.

11. DAVIS, B. \& LAZARUS, N.R. An in vitro sy stem for studying insulin release: effects of glucose and glucose-6-phosphate. J. Physiol., 271: 273-88, 1977

12. DELATTRE, E.; SANTOS, M.L; SANTOS, M.L. Inhibition of
BOSCHERO, A.C. Effect of gentamycin upon insulin release and $45 \mathrm{Ca}$ net uptake by isolated islets. Experientia, 38: 1320-1, 1982 .

13. DEVIS, G.; SOMERS, G.; MALAISSE, W.J. Stimulation of insulin release by calcium. Biochem. biophys. Res. Commun., 67: 525-9, 1975.

14. ---. Dy namics of calcium-induced insulin release. Diabetologia, 13: $531-6,1977$.

15. DEVIS, G.; SOMERS, G.; VAN OBBERGHEN, E; MALAISSE, W.J. Calcium antagonists and islet function I. Inhibition of insulin release by verapamil. Diabetes, 24 : 547-51, 1975.

16. DOUGLAS, W.W. Stimulus-secretion coupling: the concept and clues from chromaffin and other cells. Brit. J. Pharmacol., 34: 451-74, 1968.

17. FUJIMOTO, W.Y \& ENSINCK, J.W. Somatostatin inhibition of insulin and glucagon secretion in rat islet culture: Reversal by ionophore A23187. Endocrinology, 98 . 259.62, 1976.

18. FUJITA, T.; SAKAGAM1, Y.; TOMITA, T.; OKAMOTO, Y.; OKU, H. Insulin secretion after oral calcium load. Endocrin. Jap., 25:645-8, 1978. 
19. GEDIK, O. \& ZILELI, M.S. Effects of hypocalcemia and theophylline on glucose tolerance and insulin release in human beings. Diabetes, 26: 813-9, 1977.

20. GEDIK, O.; AKALIN, S.; KORAY, Z. Effect of acute hypercalcaemia on glucose tolerance and insulin release in human beings. Acta endocr., Copenhagen, 94: 196-200, 1980.

21. GERO, L.; BARANYI, Ë.; STECZEK, K.; PETRÁNYI, Jr.,GY., TAMĀS $\mathrm{Jr}_{\mathrm{r}}$, Gy; Pontentiation of glibenclamide-induced insulin release by calcium infusion. Diabetologia, 13: $35 \mathrm{I}-4,1977$

22. GRODSKY, G.M. \& BENNETT, L.L Cation requirements for insulin secretion in the isolated perfused pancreas. Diabetes, 15:910-3, 1966.

23 HALES, C.N.; CAMPBELL, A.K.; LUZIO, J.P.; SIDDLE, K. Calcium as a mediator of hormone action. Biochem. Soc. Trans, , 5: 866.71, I977.

24. HARTER, H.R.; S ANTIAGO, J.V.; RUTHERFORD, W.E.; SLATOPOLSKY, E.; KLAHR, S. The relative roles of calcium, phosphorus, and parathyroid hormone in glucose-and tolbutamide-mediated insulin release. $J$. clin. Invest., 58: 359-67, 1976.

25. HEDESKOV, C.J. Mechanism of glucose-induced insulin secretion. Physiol. Rev., 60:442-509, 1980.

26. HELLMAN, B. The significance of calcium for glucose stimulation of insulin release. Endocrinology, 97: 392-8, 1975.

27. $-\ldots--$. Stimulation of insulin release after raising ex tracellular calcium. FEBS Letters, 63: 125-8, 1976.

28. - - - Calcium and pancreatic B-cell function I. Stimulatory effects of pentobarbital on insulin release. Biochim. biophys. Acta, 497 . 766-74, 1977.

29. HENQUIN, J. - C. Relative importance of extracellular and intracellular calcium for the two plases of glucosestimulated insulin release: studies with theophylline. Endocrinology, 102: 723-30, 1978.

30. HENQUIN, J. - C. \& LAMBERT, A.E. Cobalt inhibition of insulin secretion and calcium uptake by isolated rat islets. Amer. J. Physiol., 228: 1669-77, 1975.

31. HERMAN, L.;SATO, T.; HALES, C.N. The electron microscopic localization of cations to pancreatic islets of Langerhans and their possible role in insulin release. J. Ultrastruct. Res., 42: 298-311, 1973.
32. HOWELL, S.L. Intracellular localization of calcium in pancreatic B-cells. Biochem. Soc. Trans., 5:875-9, 1977.

33. HOWELL, S.L. \& TYHURST, M. $45_{\text {Calcium localization in islets }}$ of Langerhans, a study by electronmicroscopic au torradiography. J. cell. Sci, 21:415-22, 1976.

34. - - - - Barium accumulation in rat pancreatic B cells. J. cell. Sci., 22 : $455-65,1976$

35. HOWELL, S.L.; MONTAGUE. W.; TYHURST, M. Calcium distribution in islets of Langerhans: a study of calcium concentrations and of calcium accumulation in B cell organelles. J. Cell Sci., 19: 395-409, 1975.

36. HUTTER, O.F. \& KOSTIAL, K. Effect of magnesium and calcium ions on the release of acetylcholine. $J$. Physiol., 124: 234-41, 1954.

37. IVERSEN, J. \& HERMANSEN, $\mathrm{K}$ Calcium, glucose and glucagon release. Diabetologia, 13: 297-303, 1977.

38. KIKUCHI, M.; WOLLHEIM, C.B.; SIEGEL, E.G.: RENOLD, A.E.; SHARP, G.W.G. Biphasic insulin release in rat islets of Langerhans and the role of intracellular $\mathrm{Ca}^{++}$ stores. Endocrinology, 105: 1013-9, 1979.

39. KUZUYA, T. ; KAJINUMA, H.; IDE, T. Effect of intrapancreatic injection of potassium and calcium on insulin and glucagon secretion in dogs. Diabetes, 23: 55-60, 1974.

40. LAMBERT, A.E.; JUNOD, A.; STAUFFACHER, $\mathrm{W}$; JEANREN AUD, 3.; RENOLD, A.E. Organ culture of fetal rat pancreas I. Insulin release induced by caffeine and by sugars and some derivatives. Biochim. biophys. Acta, 184:529-39, 1969.

41. LITTLEDIKE, E.T.; WITZEL, D.A.; WHIPP, S.C. Insulin: evidence for inhibition of release in spontaneous hypocalcemia, Proc. soc. exp. Biol., 129: 135-9, 1968.

42. LUNDQUIST, I.; FANSKA, R.; GRODSKY, G.M. Interaction of calcium and glucose on glucagon secretion. Endocrinology, 99: 1304-12, 1976.

43. MALAISSE, W.J. Role of calcium in insulin secretion. Israel $J$. med. Sci., 8: 244-51, 1972.

44. -- - Insulin secretion: multifactorial regulation for a single process of release. Diabetologia, 9: 167.73, 1973.
45. - --. Role or cations. In: BORN G.V.R. et alii, eds. Handbook of Experimental Pharmacology. Berlin, Springer-Verlag, 1975. v. 32 pt. 2, cap. 5, p. $145-55$.

46. - - - Calcium-antagonists and islet function. $X$. Effect of suloctidil. Arch. int. Pharmacodyn, 228: 339-44, 1977.

47. MALAISSE, W.J. \& PIPELEERS, D.G. The role of cations in insulin synthesis and release. In: CONGRESS of the INTERNATIONAL DIABETES FEDERATION, 8., Brussels, 1973. Proceedings. Amsterdam, Excerpta Médica, 1973. p. 95-103. (Series 312 - Diabetes).

48. MALAISSE, W.J. \& BOSCHERO, A.C. Calcium antagonists and islet function XI. Effect of nifedipine. Hormone Res., 8 203-9, 1977.

49. MALAISSE, W.J.; BRISSON, G.; MALAISSE-LAGAE, $F$. The stimulus-secretion coupling of glucose-induced insulin release I. Interaction of epinephrine and alkaline earth cations. $J$. Lab. clin. Med., 76: 895-902, 1970.

50. MALAISSE, W.J.;BRISSON, G.; BAIRD, L.E. Stimulus-secretion coupling of glucose-induced insulin release, $X$. Effect of glucose on ${ }^{45} \mathrm{Ca}$ efflux from perifused islets. Amer. J. Physiol., 224: 389-94, 1973.

51. MALAISSE, W.J.: MALAISSE-LAGAE, F.; WALKER, M.O.; LACY, P.E. The stimulus-secretion coupling of glucose-induced insulin release $V$. The participation of a microtubular-microfilamentous system. Diabetes, 20: 257-65, 1971.

52. MALAISSE, W.J.; MAHY, M.; BRISSON, G.R.; MALAISSELAGAE, F. The stimulus-secretion coupling of glucose-induced insulin release VIII. Combined effects of glucose and sulfonylureas. Europ. J. clin. Invest., 2: 85-90, 1972.

53. MALAISSE, W.J.; DEVIS, G.; PIPELEERS, D.G.; SOMERS, G. Calcium-antagonists and islet function. IV. Effect of D600. Diabetologia, 12:77-81, 1976.

54. MALAISSE, W.J.; SENER. A.; DEVIS, G.; SOMERS, G. Calciumantagonists and islet tunction $\mathrm{V}$. Effect of R33711. Horm, metabol. Res., 8: 434-8, 1976.

55. MALAISSE, W.J.; HERCHUELZ, A.; LEVY, J.; SENER, A. Calcium antagonists and islet function - III The possible site of action of - verapamil. Biochem. Pharmacol., 26:735-40, 1977. 
56. MALAISSE, W.J.; DEVIS, G.; HERCHUELZ, A. ; SENER, A.; SOMERS, G. Calcium antagonists and islet function VIII. The effect of magnesium. Diabete 8 Metabol, Paris, 2: 1-4, 1976.

57. MALAISSE, W.J.; HUTTON, J.C.; SENER, A.: LEVY. J.: HERCHUELZ, A.; DEVIS, G.; SOMERS, G. Calcium antagonists and islet function: VII. Effect of calcium deprivation. $J$. Membrane Biol., 38: 193-208, 1978

58. MALAISSE, W.J.; HERCHUELZ, A.; DEVIS, G.; SOMERS, G.; BOSCHERO, A.C.; HUTTON, J.C.; KAWAZU, S.; SENER, A.; ATWATER, I.J.; DUNCAN, G.; RIBALET, B.; ROJAS, E. Regulation of calcium fluxes and their regulatory roles in pacreatic islets. Ann. N.Y. Acad. Sci, 307: 562-82, 1978.

59. MILNER, R.D.G. \& HALES, C.N. The role of calcium and magnesium in insulin secretion from rabbit pancreas studied in vitro. Diabetologia, 3: 47-9, 1967.
60. PIPELEERS, D.G.; MARICHAL, M.; MALAISSE, W.J. The stimulussecretion coupling of glu cose-induced insulin release. XV. Participation of cations in the recognition of glucose by the B-cell. Endocrinology, 93: 1012-8, 1973.

61. RUBIN, R.P. The role of calcium in the release of neurotransmitter substances and hormones. Pharmacol, Rev., 22: 389-428, 1970

62. Calcium and the secretory process. New York, Plenum Press, 1974.

63. SOMERS, G.; DEVIS, G.; VAN OBBERGHEN, E. ; MALAISSE, W.J, Calcium antagonists and islet function. II. Interaction of theophylline and verapamil. Endocrinology, 99: 114-24, 1976.

64. WILLIAMS, J.A. Effects of $\mathrm{Ca}^{++}$ and $\mathrm{Mg}^{++}$on secretion in vitro by mouse thyroid glands. Endocrinology, 90: 1459-63, 1972.

65. WITZEL, D.A. \& LITTLEDIKE, E.T.
Supression of insulin secretion during induced hypocalcemia.

Endocrinology, 93: 761-6, 1973.

66. WOLLHEIM, C.B. \& SHARP, G.W.G. Regulation of insulin release by calcium. Physiol. Rev., 61 914-73, 1981.

67. - - - ; ; KIKUCHI, M.; RENOLD, A.E.; SHARP, G.W.G. The roles of intracellular and extracellular $\mathrm{Ca}^{++}$ in glucose-stimulated biphasic insulin release by rat islets. $J$. clin. Invest., 62:451-8, 1978.

68. - - ; BLONDEL, B.; TRUEHEART, P.A.; RENOLD, A.E.; SHARP, G.W.G. Calcium-induced insulin release in monolayer culture of the endocrine pancreas - Studies with ionophore A23187. J. biol. Chem. $250 \cdot 1354-60,1975$

69. YASUDA, K.; HURUKAWA, Y.; OKUYAMA, M.; KIKUCHI, M.; YOSHINAGA, K. Glucose tolerance and insulin secretion in patients with parathyroid disorders - Effect of serum calcium on insulin release. New Engl. J. Med., 292: 501-4, 1975. 